\title{
Evaluation of Nitrogen Mineralization in Soil Polluted by Zinc and Cadmium
}

\author{
Buddhi Charana Walpola, K.K.I.U. Arunakumara ${ }^{1}$, and Min-Ho Yoon ${ }^{2} *$ \\ Department of Soil Science, Faculty of Agriculture, University of Ruhuna, Mapalana, Kamburupitiya, Sri Lanka \\ ${ }^{1}$ Department of Crop Science, Faculty of Agriculture, University of Ruhuna, Mapalana, Kamburupitiya, Sri Lanka \\ ${ }^{2}$ Department of Bio-Environmental Chemistry, College of Agriculture and Life Sciences, \\ Chungnam National University, Daejeon, 305-764, Korea
}

\begin{abstract}
Soil microbial functions are considered to be effective in assessing the severity of heavy metal pollution. Therefore, this study was carried out to examine the effect of heavy metals on nitrogen mineralization by measuring the releasing pattem of inorganic nitrogen $\left(\mathrm{NH}_{4}{ }^{+}-\mathrm{N}\right.$ and $\left.\mathrm{NO}_{3}{ }^{-}-\mathrm{N}\right)$ in a soil treated with heavy metals. A factorial combination of two heavy metals $(\mathrm{Zn}$ and $\mathrm{Cd})$ treated with three concentrations $(50,100$ and $150 \mu \mathrm{mol} \mathrm{g}^{-1}$ soils) was used in a laboratory incubation. Nitrogen mineralization was determined at 3,7 , $14,21,28,42$ and 56 days after the treatments replicated four times. Soil sample free from heavy metals was served as the control. The amount of nitrogen mineralization from heavy metal treated soils was found to be decreased at an increasing rate during the first 21 days of incubation. However, as the incubation progressed, nitrogen mineralization was found to be decreased at decreasing rates. Furthermore, during this period, nitrogen mineralization in $\mathrm{Cd}$ treated soils was significantly lower $(\mathrm{P} \leq 0.05)$ than that of the control. Soils treated with $\mathrm{Cd}$ at the concentration of $150 \mu \mathrm{mol} \mathrm{g} \mathrm{g}^{-1}$ showed the lowest $\mathrm{N}$ mineralization throughout the incubation. Nitrogen mineralization in $\mathrm{Zn}$ treated soils $\left(50 \mu \mathrm{mol} \mathrm{g}^{-1}\right)$ was found to be higher than the other heavy metal treated soils. On the base of present findings, nitrogen mineralization of soil could be considered as a viable assessment of the degree of heavy metal pollution.
\end{abstract}

Key words: Heavy metals, Incubation, Nitrogen mineralization

\section{Introduction}

Heavy metal contamination of soil through anthropogenic activities is a serious environmental issue all over the world. Mining, smelting of metalliferous ores and metal scraps, electroplating, application of fertilizer and pesticides, sludge dumping and generation of municipal waste have been identified as the principal sources of soil contamination by heavy metals (Kebir and Bouhadjera, 2011). The soil microbial population is under tremendous pressure due to these toxic substances (Chaudhary et al., 1996). Soil microorganisms are among the first to experience the negative impacts of pollutants, thus their population and diversity can be used as an index to assess the degree of pollution in the environment (Ultra et al., 2005). Many reports indicate that heavy metals interfere with the biochemistry of diverse group of microorganisms isolated

\footnotetext{
Received : July 13. 2011 Accepted : July 29. 2011

*Corresponding author : Phone: +82428216733

E-mail: mhyoon@cnu.ac.kr
}

from their natural environments (Sani et al., 2003; Utgikar et al., 2004). The availability of metals is primarily determined by metals binding to: (1) Clay minerals, leading to a significant decrease in the water soluble and exchangeable varieties of heavy metals (Usman et al., 2005); or (2) metals binding to either Fe/Mn oxides or carbonate complexes (Reddy et al., 2010). Tolerance to toxic metals is strongly correlated to the concentrations of the metals as reported by Ogilvie and Grant (2008) for $\mathrm{Cu}$. Soil microorganisms can however become adapted to the effects of heavy metals if toxic elements have been present in the soil for long periods of time (Chander and Joergensen, 2008).

Heavy metals at elevated concentrations are known have direct impacts on soil fertility as they could alter soil microbial population and their associated activities. The magnitude of the microbial diversity makes it difficult to study the whole spectrum of population. However, certain important functional groups such as ammonifying, nitrifying, nitrogen fixing, cellulytic and lignolytic microorganisms have often been investigated. Zinc (Zn) and 
Cadmium $(\mathrm{Cd})$ are naturally found in small amounts in soils. Cadmium acts as a potentially toxic metal in soil environment by unknown biological function. Zinc as a micronutrient is an essential element to maintain metabolic functions of living organisms. However, at elevated concentrations, both essential and nonessential elements may have a potential risk to terrestrial environments. Typical $\mathrm{Cd}$ and $\mathrm{Zn}$ contents of uncontaminated soils are less than 0.5 and $10-80 \mathrm{mg} \mathrm{kg}^{-1}$ soil, respectively (Scheffer and Schachtschabel, 2002). However, intensified anthropogenic activities, such as mining, application of sewage sludge, industrial waste disposal and agricultural activities lead to elevate $\mathrm{Zn}$ and $\mathrm{Cd}$ concentration in soils. Under this background, the present study was undertaken to study the effect of heavy metals on microbial activity as measured by nitrogen mineralization of soil.

\section{Materials and Methods}

Experimental Area and Soil The experiment was conducted at the Faculty of Agriculture, University of Ruhuna, Sri Lanka. According to the agro-ecological classification (Panabokke, 1980), the region of investigation comes under agro-ecological region $\mathrm{WL}_{2}$ (low country wet zone). The soil used in this study belongs to Red Yellow Podzolic great soil group and is classified as Hapludults according to the USDA soil taxonomy (Mapa et al., 1999). The climate of the area is tropical monsoonal (Panabokke, 1980), with a warm wet period (April to June) and a relatively dry period (January to March). The area receives an annual rainfall of around 2,500 mm. The distribution of rain is bi-model. Annual mean air temperature of the area is $22-30^{\circ} \mathrm{C}$ and the relative humidity is about $80 \%$.

Soil Sampling Soil samples were collected randomly from several selected locations at the research farm of Faculty of Agriculture, University of Ruhuna, Sri Lanka. After removing the surface litter, soil samples were taken from $0-15 \mathrm{~cm}$ depth by using an auger. They were then mixed thoroughly in order to make a composite sample. Physico-chemical characteristics of the soil were determined using standard methods (Table 1).

Treatments Sub samples of $50 \mathrm{~g}$ of homogeneously mixed air dried soil were placed in glass bottles. Bottles were watered to adjust the moisture content to $50 \%$ of
Table 1. Physicochemical properties of soil.

\begin{tabular}{lc}
\hline \hline Property & Value \\
\hline Sand (\%) & 60.4 \\
Silt (\%) & 30.8 \\
Clay (\%) & 7.6 \\
Soil pH & 5.15 \\
Soil moisture content & 5.7 \\
Soil C (\%) & 1.008 \\
Soil N (\%) & 0.126 \\
Soil EC (dS cm $\left.{ }^{-1}\right)$ & 0.15 \\
Soil CEC (cmol kg $\left.{ }^{-1}\right)$ & 9.05 \\
Soil bulk density $\left(\mathrm{g}^{-3}\right)$ & 1.74 \\
\hline
\end{tabular}

the field capacity (dry basis) and maintained by daily monitoring and adding water when necessary. Bottles were then kept in dark for two weeks prior to addition of treatments. After two-week pre-incubation period, the glass bottles were opened and $50 \mu \mathrm{mol}, 100 \mu \mathrm{mol}, 150$ $\mu \mathrm{mol}$ of $\mathrm{CdCl}_{2}$ and $\mathrm{ZnCl}_{2}$, were added separately and mixed thoroughly with the soil. Soil samples without being treated with heavy metals were used as control. The treated soil samples along with the controls were incubated in the dark at room temperature $\left(25 \pm 1^{\circ} \mathrm{C}\right)$. Constant moisture content of the soil was maintained throughout the incubation period.

Nitrogen Mineralization Nitrogen mineralization was determined in terms of inorganic $\mathrm{N}\left(\mathrm{NH}_{4}{ }^{+}-\mathrm{N}\right.$ and $\left.\mathrm{NO}_{3}{ }^{-} \mathrm{-}\right)$ at 3, 7, 14, 21, 28, 42 and 56 days after incubation. Samples containing $10 \mathrm{~g}$ soil were extracted using $30 \mathrm{~mL}$ of $2 \mathrm{M}$ $\mathrm{KCl}$ and the extracts were used in determining $\mathrm{NH}_{4}{ }^{+} \mathrm{N}$ and $\mathrm{NO}_{3}{ }^{-} \mathrm{N}$. The $\mathrm{NH}_{4}{ }^{+}-\mathrm{N}$ content was determined utilizing Berthelot reaction (Searle, 1984) and the $\mathrm{NO}_{3}{ }^{-} \mathrm{N}$ by sodium salicylate yellow color method (Bremner, 1982) using a spectrophotometer (UV 160) at $640 \mathrm{~nm}$ and $410 \mathrm{~nm}$, respectively. Simultaneously, soil moisture content was measured gravimetrically in same intervals. Water holding capacity was maintained at the rate of $50 \%$ and four replicates were followed.

Statistical Analysis Data generated were analyzed as a completely randomized design with four replicates at $95 \%$ confidence interval, using analysis of variance (ANOVA) of SAS software (SAS Institute, 1989) DMS at $\mathrm{P} \leq 0.05$ was used to compare and separate. 


\section{Results and Discussion}

The periodical changes in $\mathrm{NH}_{4}{ }^{+}-\mathrm{N}$ and $\mathrm{NO}_{3}{ }^{-}-\mathrm{N}$ mineralization of soils amended by heavy metals, $\mathrm{Cd}$ and $\mathrm{Zn}$, are depicted in figure 1 and 2, respectively. As illustrated in figure 1 and 2, both $\mathrm{NH}_{4}^{+}-\mathrm{N}$ and $\mathrm{NO}_{3}{ }^{-}-\mathrm{N}$ mineralization showed a similar pattern throughout the incubation. The amount of nitrogen mineralization from the tested heavy metal treated soils was found to be decreased at an increasing rate during the first 21 days followed by decreasing rates as incubation progressed. A possible reason for the initial decrease in nitrogen mineralization at an increasing rate of may be due to the toxicity of the heavy metal. It is further indicated from the results that a considerable period of time is needed for the adaptation of microorganisms. Soils treated with $\mathrm{Zn}$ at the concentration of $50 \mu \mathrm{mol} \mathrm{g}^{-1}$ showed relatively higher nitrogen mineralization than the other treatments, whereas $\mathrm{Cd}$ at the concentration of $150 \mu \mathrm{mol} \mathrm{g}^{-1}$ exhibited the lowest nitrogen mineralization throughout the incubation. Microorganisms differ in their sensitivity to metal toxicity and elevated metal exposure will result in immediate death of cells due to disruption of essential functions, and to more gradual changes in population sizes due to changes in viability or competitive ability.

At the beginning of the incubation, $\mathrm{NH}_{4}{ }^{+}-\mathrm{N}$ mineralization of $\mathrm{Zn}$ treated soils were 40.7, 33.3 and $33.1 \mathrm{mg}$ $\mathrm{kg}^{-1}$ soil respectively for the concentrations of 50,100 and $150 \mu \mathrm{mol} \mathrm{g}^{-1}$ of soil. The corresponding figures at the end of the incubation period (after 56 days) were just 12.8, 12.5 and $8.2 \mathrm{mg} \mathrm{kg}^{-1}$ soil for the respective treatments. In the case of $\mathrm{Cd}$ treated soils, lower $\mathrm{NH}_{4}{ }^{+}-\mathrm{N}$ mineralization was recorded both at the beginning $(35,33.6$ and $29.3 \mathrm{mg}$ $\mathrm{kg}^{-1}$ soil) and the end $\left(10.7,6.6\right.$ and $6.4 \mathrm{mg} \mathrm{kg}^{-1}$ soil) of the incubation for the treatments of 50,100 and $150 \mu \mathrm{mol} \mathrm{g}^{-1}$, respectively.

According to the results, the lowest and the highest inhibitory effect of $\mathrm{NH}_{4}{ }^{+} \mathrm{N}$ mineralization in heavy metal

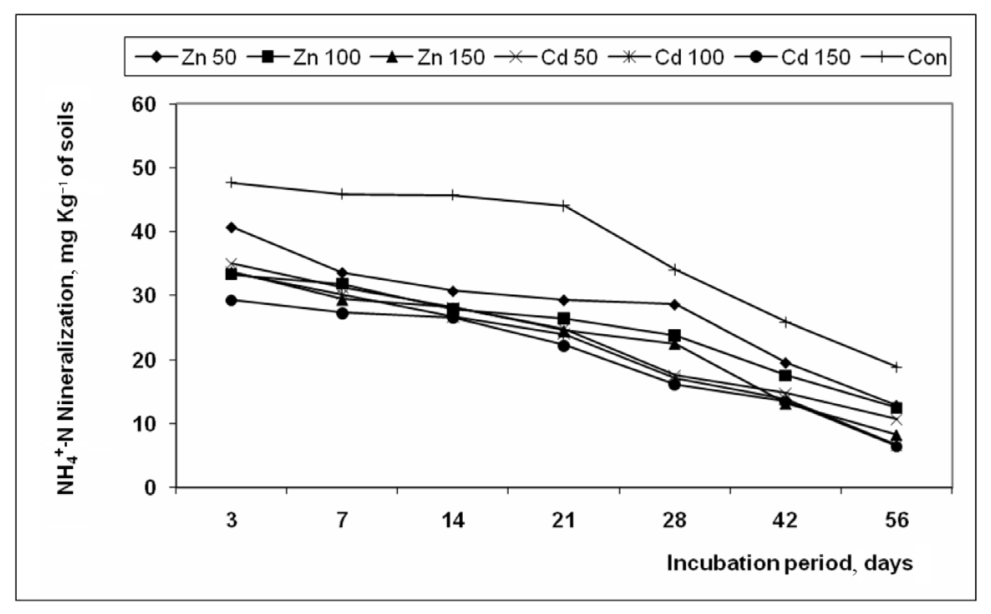

Fig. $1 . \mathrm{NH}_{4}{ }^{+} \mathrm{N}$ mineralization of the soil treated with different heavy metals. Values given here are the means $(\mathrm{n}=4) \pm \mathrm{SD}$.

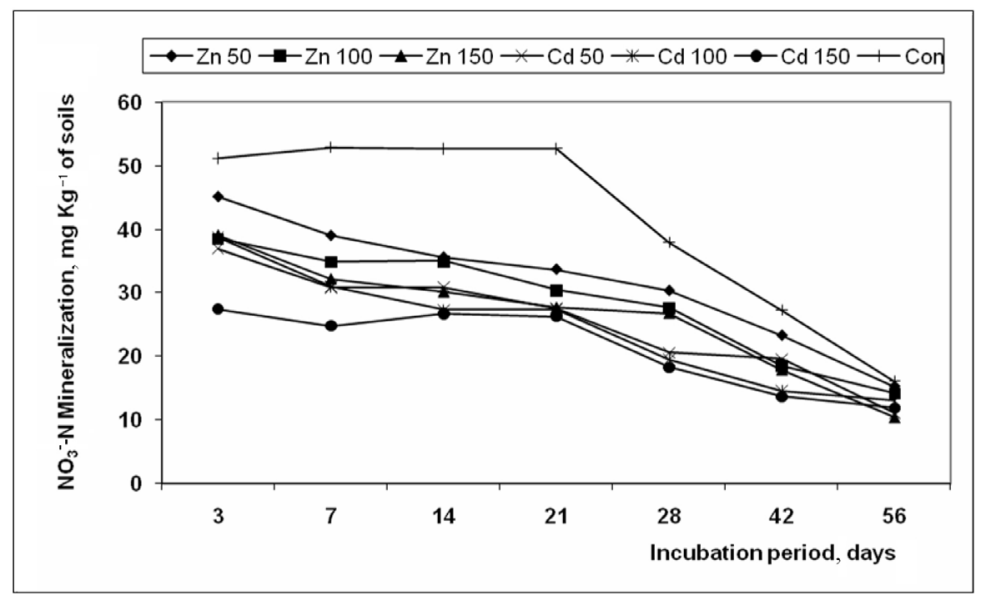

Fig. 2. $\mathrm{NO}_{3}^{-}-\mathrm{N}$ mineralization of the soil treated with different heavy metals. Values given here are the means $(\mathrm{n}=4) \pm \mathrm{SD}$. 
treated soils was recorded from the soils treated with $\mathrm{Cd}$ at $150 \mu \mathrm{mol} \mathrm{g}^{-1}$ and $\mathrm{Zn}$ at $50 \mu \mathrm{mol} \mathrm{g}^{-1}$ (Fig. 3), respectively. As the incubation progressed, gradual decline in $\mathrm{NH}_{4}{ }^{+}-\mathrm{N}$ mineralization was observed in all the treatments including the control. Though the highest rate of $\mathrm{NH}_{4}{ }^{+}-\mathrm{N}$ mineralization was recorded from the control, no significant differences $(\mathrm{P} \leq 0.05)$ were found among the treatments during the initial period of incubation. However, after 21 days of incubation, the rate of $\mathrm{NH}_{4}{ }^{+}-\mathrm{N}$ mineralization in $\mathrm{Cd}$ treated soils $(150 \mu \mathrm{mol} \mathrm{g})$ was significantly $(\mathrm{P} \leq$ $0.05)$ lower than the other treatments.

The initial figures of $\mathrm{NO}_{3}^{-}-\mathrm{N}$ mineralization in $\mathrm{Zn}$ treated soils were $45.1,38.5$ and $37.5 \mathrm{mg} \mathrm{kg}^{-1}$ soil, respectively for the treatments of 50,100 and $150 \mu \mathrm{mol} \mathrm{g}^{-1}$ of soil. At the end of the incubation (after 56 days) the respective values were found to be changed to $15.3,14.2$ and $10.4 \mathrm{mg}$ $\mathrm{kg}^{-1}$ soil. The respective values for the $\mathrm{Cd}$ applied soils were $36.9,35.7$ and $27.4 \mathrm{mg} \mathrm{kg}^{-1}$ soil for the treatments of 50,100 and $150 \mu \mathrm{mol} \mathrm{g}^{-1}$ at the beginning of the incubation and 11.1, 11.1 and $10.8 \mathrm{mg} \mathrm{g}^{-1}$ soil for respective treatments at the end of the incubation. Similar to $\mathrm{NH}_{4}{ }^{+}-\mathrm{N}$ mineralization $\mathrm{Cd}$ with $150 \mu \mathrm{mol} \mathrm{g}{ }^{-1}$ amended soil showed the highest $\mathrm{NH}_{4}{ }^{+}-\mathrm{N}$ mineralization inhibitory effect and the $\mathrm{Zn}$ with $50 \mu \mathrm{mol} \mathrm{g} \mathrm{g}^{-1}$ amended soil showed the lowest $\mathrm{NO}_{3}^{-}-\mathrm{N}$ mineralization inhibitory effect through out the incubation period (Fig. 4). Similar to $\mathrm{NH}_{4}{ }^{+}-\mathrm{N}$ mineralization there was no significant difference $(\mathrm{P} \leq 0.05)$ among treatments at the beginning of the incubation. However, after 21 days of incubation, $\mathrm{Cd}\left(150 \mu \mathrm{mol} \mathrm{g}^{-1}\right)$ treated samples showed the significant difference $(\mathrm{P} \leq 0.05)$ until the end of the incubation.

Important factors which influence microbe-metal interactions in soil include $\mathrm{pH}$, the quantity and quality of clay minerals as well as other complex interaction involving the metal ions and other inorganic constituents (Nwuche and Ugoji, 2008). Net nitrogen mineralization under field conditions was reported to be inhibited by the heavy metals, thus it seems to be a sensitive indicator of metal

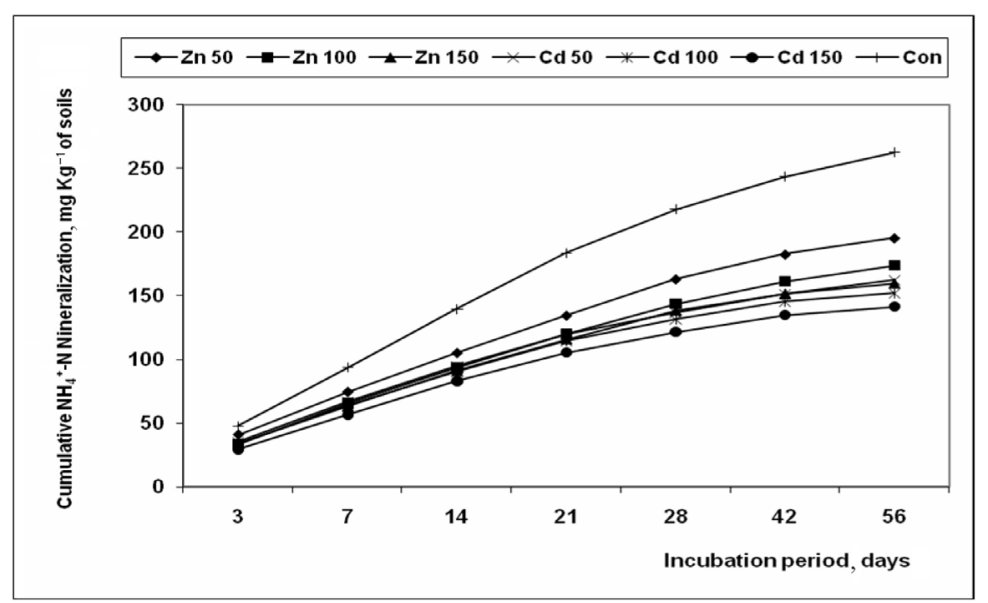

Fig. 3. Cumulative $\mathrm{NH}_{4}{ }^{+}-\mathrm{N}$ mineralization of the soil treated with different heavy metals. Values given here are the means $(n=4) \pm S D$.

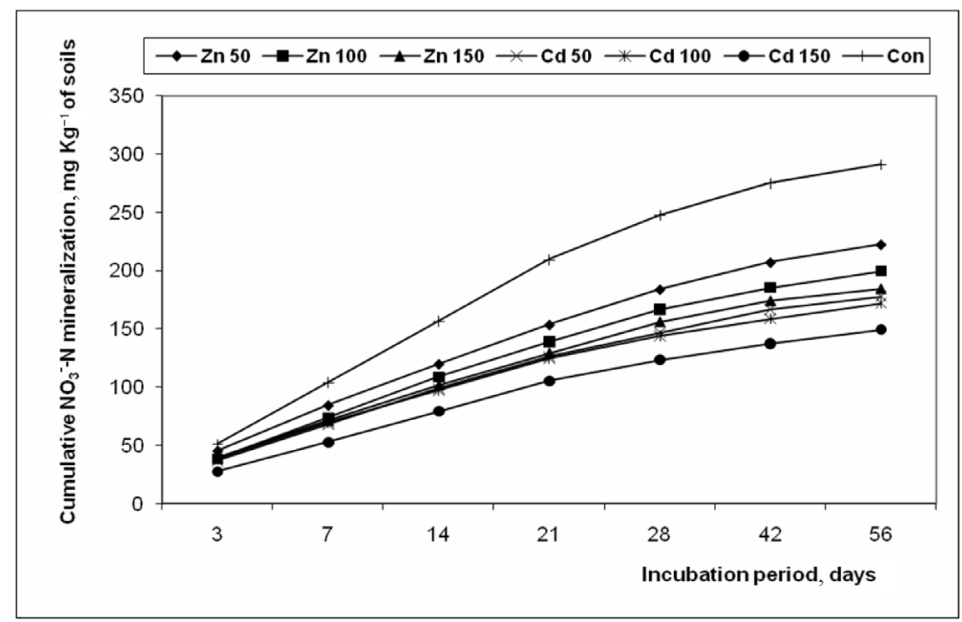

Fig. 4. Cumulative $\mathrm{NO}_{3}^{-}-\mathrm{N}$ mineralization of the soil treated with different heavy metals. Values given here are the means $(n=4) \pm \mathrm{SD}$. 
pollution (Inubushi et al., 2000; Stuczynski et al., 2003; Hinijosa et al., 2004). This was further confirmed by Min Lio (2005), who studied soil microbial parameters of a soil polluted with heavy metals and reported an increased ED50 (Ecological dosage) over time for different heavy metals. However the results from laboratory experiments are less clear, since nitrogen mineralization has been shown to be stimulated, inhibited or unchanged due to heavy metal pollution (Stuczynski et al., 2003). Due to contradictory results which have been produced by different investigations, sound conclusion is not yet to make. In fact, the inconsistent results might be due to different experimental procedures and variability in soil properties and or organic nitrogen concentration. However, present findings are also in agreement with Yao et al., (2000) who suggested that nitrogen mineralization can be used as possible indicators of soil environmental quality in toxicity assays.

\section{Conclusion}

The apparent results showed that the microbial process of nitrogen mineralization was inhibited to varied extents by the tested metals and the nitrogen mineralization of the soil has been altered by addition of $\mathrm{Zn}$ and $\mathrm{Cd}$. Especially, $\mathrm{Cd}$ was shown to display higher inhibitory effect on nitrogen mineralization than $\mathrm{Zn}$. This could therefore suggested that the metals of concern to soil microorganisms and their concentrations are the decisive factors determining the degree of inhibition. The impact of heavy metals on nitrogen mineralization is likely to be related to tolerance and adaptation of the microbial community to the concentration and type of pollutants. Therefore, nitrogen mineralization can be considered as a potential indicator of heavy metal pollution of soil environment.

\section{Acknowledgements}

The authors acknowledge the technical assistance given by the staff members of the Department of Soil Science, Faculty of Agriculture, University of Ruhuna, Sri lanka.

\section{References}

Bremner, J.M. and C.S. Mulvaney. 1982. Total nitrogen. In. A.L. Page (ed.) Methods of Soil Analysis. Part 2. Chemical and
Microbiological Methods. $2^{\text {nd }}$ Edition. Am. Soc. Agron. 1149-178. Chander, K. and R.G. Joergensen. 2008. Decomposition of Znrich Arabidopsis halleri litter in low and high metal soil in the presence and absence of EDTA. Water Air Soil Pollut. 195-204

Chaudhary, A.M., S.P. MacGrath, B.P. Knight, D.L. Johnson, and K.C. Jones. 1996. Toxicity of organic compounds to the indigenous population of $R$. leguminosorum bv. trifolii in soil. Soil Biol. Biochem. 28:1483-1487.

Hinojosa, M.B., R. Garcia-Ruiz, B. Vinegla, and J.A. Carreira. 2004. Microbiological rates and enzyme activities as indicators of functionality in soils affected by the Aznalcollar toxic spill. Soil Biol. Biochem. 36:1637-1644.

Inbushi, K., S. Goyal, K. Sakamoto, Y. Wada, K. Yamakawa, and T. Arai. 2000. Influences of application of sewage sludge compost on $\mathrm{N}_{2} \mathrm{O}$ production in soils. Chemosh-Global chang Sci. 2:329-334.

Kebir, T. and K. Bouhadjera. 2011. Heavy metal concentrations in agricultural soils and accumulation in plants growing near of dumpsite of ghazaouet (west of algeria) In. J. of Current Res. 2:042-049.

Mapa, R.B., S. Somssiri, and S. Nagarajah. 1999. Soils of the wet zone of Sri Lanka. Soil Sci. Soc. S.L. Sri Lanka. 23-92.

Min, L., L. Yun-kuo, Z. Xiao-min, and H. Chang-yong. 2005. Toxicity of cadmium to soil microbial biomass and its activity: Effect of incubation time on $\mathrm{Cd}$ ecological dose in a paddy soil. J. Zhejiang Univ. Sci. B. 6:324-330.

Nwuche, C.O. and E.O. Ugoji. 2008. Effects of heavy metal pollution on the soil microbial activity. Int. J. Environ. Sci. Tech. 5:409-414.

Ogilvie, L.A. and A. Grant. 2008. Linking pollution induced community tolerance (PICT) and microbial community structure in chronically metal polluted estuarine sediments. Mar. Environ. Res. 65:187-198.

Panabokke, C.R. 1980. Handbook of the soils of Sri Lanka. J. soil Sci. Soc. 2:83-85.

Reddy, K.R., S. Danda, Y. Yukselen-Aksoy, and A.Z. Al-Hamdan. 2010. Sequestration of heavy metals in soils from two polluted industrial sites: implications for remediation. Land Contam. Reclam. 18:13-23.

Sani, R.K., B.M. Peyton, and M. Jadhyala. 2003. Toxicity of lead in aqueous medium to Desulfovibrio desulfuricans G20. Environ. Toxicol. 22:252-260.

SAS Institute. 1988. SAS/STAT user's guide, Release 6.03. SAS Institute, Cary, North Carolina, USA.

Scheffer, F. and P. Schachtschabel. 2002. Lehrbuch der Bodenkunde. Auflage, vol. 15. Spektrum Akademischer Verlag, Heidelberg, Berlin.

Searle, P.L. 1984. The Berthelot or indophenol reaction and its use in the analytical chemistry of nitrogen: a review, Analyst 109:549-568.

Stuczynski, T.I., G.W. McCarty, and G. Siebielec. 2003. Response of soil microbiological activities to $\mathrm{Cd}, \mathrm{Pb}$ and $\mathrm{Zn}$ amendments. J. Environ. Qual. 32:1346-1355.

Ultra, Jr V.U., A. Yano, K. Iwasaki, S. Tanaka, Y.M. Kang, and K. Sakurai. 2005. Influence of chelating agent addition on copper distribution and microbial activity in soil and copper 
uptake by brown mustard (Brassica juncea). Soil Sci. Plant Nutr. 51:193-202.

Usman, A., Y. Kuzyakov, and K. Stahr. 2005. Effect of clay minerals on immobilization of heavy metals and microbial activity in a sewage sludge-contaminated soil. J. Soils Sediments 5:245-252.

Utgikar, V.P., N. Chaudhary, A. Koeniger, H.H. Tabak, J.R. Haines, and R. Govind. 2004. Toxicity of metals and metal mixtures:
Analysis of concentration and time dependence for zinc and copper. Water Res. 38:3651-3658.

Yao, H.Y., Z.L. He, M.J. Wilson, and C.D. Campbell. 2000. Microbial biomass and community structure in a sequence of soils with increasing fertility and changing land use. Microb. Ecol. 40:223-237. 